\title{
ARBITRATION IN THE SETTLEMENT OF INTERNATIONAL TRADE DISPUTES
}

\author{
MORRIS S. ROSENTHAZ*
}

\section{Commercial Disputres as a Barrier to International Trade}

When barriers to international trade are discussed, those that are usually thought of are high tariffs, customs red tape, foreign exchange controls, trade discriminations, restrictive cartel practices, and other regulations and curbs, governmental and private, which add to the normal difficulties of trade among nations. Commercial disputes between traders are rarely thought of as a barrier to international trade expansion. And yet, a great many medium-sized and small companies find themselves in trouble when they have disagreements with their customers or their sources of supply in other countries of the world and must think in terms of law suits or losses or both. Larger companies are not as adversely affected by the expenses resulting from disputes with companies in other countries of the world as they can better afford to proscute in courts of law and go through the series af appeals until a decision comes down from the highest court of the land. Or, because of their great prestige, position and wealth they can frequently compel favorable settlement of a dispute.

In the post World War II world, we not only expect but know that we must have an expanded international exchange of goods and services among all nations of the world, including our own. During the expansive years ahead, there will inevitably be an increasing number of disputes between sellers and buyers as the number of entrepreneurs grows and the volume of international trade expands. As after World War I, there will be many cases of buyers and sellers who attempt to avoid their contractual obligations when their contracts of sale and purchase are no longer profitable. There will be controversies over failure to ship or to deliver, over late shipments or deliveries, over merchandise inferior in quality, over refusal to accept delivery of goods, over claims that no contract ever existed between the parties, over differing interpretations of foreign trade definitions which set forth the risks of seller and buyer while the goods are in transit, over interpretation of marine insur-

*A.B., I917, Columbia University. Executive Vice-President, Stein, Hall \& Company, Inc.; VicePresident, National Council of American Importers; Special Consultant to Senate Sub-Committee on Forcign Trade; Lecturer on Foreign Trade, Columbia University. Officer, consultant and adviser to numerous organizations on foreign trade matters. Member of: Advisory Editorial Board of the International Arbitration Journal of the American Arbitration Association; Import Advisory Committce to the Department of Commerce; Advisory Committee to the Departments of State and Commerce on the Commercial Activities of the Foreign Service; Industrial and Commercial Panels of the American Arbitration Association. Ass't Director, Board of Economic Warfare, I94I-1943. Author: Technical ProCEDURE IN EXPORTING AND IMPORTING (1922). 
ance that should have been supplied, over terms of payment, foreign exchange regulations, and the many other technical factors that enter into a foreign trade transaction from the time that an exporter receives and accepts an order and the importer receives and accepts the goods.

Commercial disputes that end in courts of law are always costly and usually bitter. Cases frequently drag through the courts for many years, and the ultimate winner of the lawsuit finds that he is out of pocket more than the amount of the judgment in his favor. Courts tend to favor their own nationals and thereby further animosity is created between peoples of different countries who grow suspicious of the kind of deal that they will get from foreign nationals. There is no body of international commercial law, and the courts of different countries have interpreted the rights and liabilities of buyers and sellers differently. Public attention resulting from cases being aired in courts has frequently added to the friction between disputants and has thereby created enough animosity to end business relationships.

An alternative method of settling international commercial disputes is commercial arbitration. It is not a new method. Centuries ago traders discovered that commercial arbitration would enable them to adjudicate their differences quickly, cheaply, privately and fairly. International commercial arbitration is not a perfect method. It has its disadvantages as well as its outstanding advantages. Unfortunately, too few of those engaged in foreign trade, aside from large companies or active dealers in staple raw materials, know in sufficient detail for their own profitable use what international commercial arbitration is, how it works and what it does.

This article is intended to discuss some of the legal considerations that the lay exporter and importer can well understand and should know in order to conduct his business properly and to settle quickly disagreements that he may have with those to whom he sells or from whom he buys. It will also discuss some of the outstanding organizations in the field of international commercial arbitration and how they work.

In urging international commercial arbitration as the most satisfactory method of settling international commercial disputes, I have given much thought to the attitude of exporters and importers toward each other when trouble arises over the fulfillment or interpretation of a contract. I have based my conclusions and recommendations on the assumption first, that most businessmen are honest in their dealings with each other, and secondly, that they want not only a speedy and economic settlement of their differences but also a fair settlement. In making these assumptions I also recognize that there are some who would always wriggle out of their undertakings if they turn out to be unprofitable and who have no regard for the decencies of business or of life and who unfortunately are still out of jail.

But those businessmen, who, in ever growing number, turn to arbitration for the settlement of their disagreements with each other, must know something of the laws of different countries of the world and of the procedures necssary to fulfill legal requirements and make arbitration awards enforcible at law. Where the in- 
tegrity of both parties to the contract is beyond reproach, where both parties even under the stresses generated by a controversy, will deal in absolute good faith, the legal and technical requirements of arbitration procedures are of subordinate importance. But the well-advised businessman must be prepared to deal effectively with the "fringe" group which, faced with the possibility of a weak or non-existent defense, will avidly exploit any deficiency in the proposed arbitration, either to circumvent it completely or to delay it inordinately. It is in this situation that to be forewarned is to be forearmed.

\section{The Merchant and the Law \\ A. The Arbitration Clause}

Voluntary arbitration is the process in which two parties to a dispute agree to submit their differences to one or more impartial persons for a decision which both parties agree to accept as binding upon them. In the field of international trade, it is customary for those sellers and buyers who wish to use arbitration as a method of settling their disagreements to include a clause in the contract of sale and purchase which provides for arbitration. It is therefore important that merchants know about the laws of the countries with which they trade pertaining to the validity of arbitration clauses. An arbitration clause in the contract is without value if, when a dispute arises, either party to the contract can refuse to arbitrate and be able in that way to avoid an obligation which he has undertaken at the time that he has made a purchase or sale. When a dispute arises, there is the danger that the party with a weak case may refuse to abide by the agreement to arbitrate. He may prefer to go to court where he can drag out the case and perhaps even obtain a favorable decision on a legal technicality quite remote from the merits of the case.

The laws of the different countries of the world pertaining to arbitration are not uniform in most of the important fundamentals. The laws of the forty-eight states of the United States are not uniform. Different countries have different laws pertaining to the validity of and to the methods of enforcing the arbitration clause. There are some international agreements whereby groups of countries recognize the validity of arbitration clauses in commercial contracts between their nationals. The merchant should know something of this so that when he enters into a contract of purchase or sale which includes an arbitration clause he has some understanding, first as to how the clause should be worded in order to comply with the laws of the countries of sale and purchase and, secondly, whether or not the laws of "these two countries will recognize the validity of the clause if a dispute afterwards arises and either party seeks to avoid arbitration as the method of settlement.

I think that the statement can fairly be made that the laws of most of the important international trading countries, except the Central and South American, recognize the validity of an agreement relating to the arbitration of either existing or future disputes, and that if a businessman signs a contract which includes an 
arbitration clause and afterwards tries to take the case to court instead of submitting it to arbitration, the courts of most of these countries will refuse to allow a court trial. However, this broad statement cannot serve as guide in a specific case. In the absence of statute, for instance, the common law view of the American states is that agreements to arbitrate future disputes are revocable-meaning, among other things, that one party can refuse to observe the arbitration clause and still take his case to court, although this power to revoke is extinguished by an award duly rendered previously. ${ }^{1}$ In fact, at common law, it is not even clear that there is a right to damages for breach of the agreement to arbitrate, ${ }^{2}$ much less the right to get an order from a court of equity to compel the recalcitrant party to arbitrate. ${ }^{3}$ Statutes in the various states are increasingly changing these common law principles."

In analyzing the laws and international agreements pertaining to the validity of arbitration clauses, I have divided the subject into three broad areas.

First, the Geneva Protocol of September 24, I923, covered most of the countries of Europe, many parts of the British Empire, Brazil and Japan. ${ }^{5}$ The signatories to the Protocol agreed to recognize the validity of an arbitration agreement between nationals of different signatory powers in which both parties undertook to submit all controversies, future or existing, in connection with a commercial contract to arbitration. There were certain reservations made pertaining to the jurisdiction of the different contracting states, but for practical purposes a merchant could assume that those countries which ratified the Geneva Protocol would uphold an arbitration clause between its nationals and would not allow the defendant in an arbitration to drag the matter into the courts and so welch on his agreement to arbitrate.

But it is important to understand that the Geneva Protocol and the laws of the ratifying countries do not necessarily compel a merchant to enter into arbitration proceedings. The courts will refuse to handle the case, but thereafter the party desiring arbitration and the arbitral tribunal might well have to proceed with the case despite the absence of the defendant. However, not all states permit an arbitration to proceed in the absence of the defendant. Under most circumstances, English tribunals can conduct such an arbitration, if the agreement provides that the arbitration is to be held pursuant to English law.

The laws of the states in this country are at great variance on this point, but under the rules of the American Arbitration Association, an arbitration may be commenced and conducted despite the refusal of the other party to participate.

Second, in the United States the two arbitration laws that are probably of

${ }^{2}$ Sturges, Commercial Arbitration and Awards (1930) 45, 57.

Id. at 82 .

${ }^{3}$ Id. at 83 .

4Id. at IIo ff.; Kronstein, Business Arbitration-Instrument of Private Government (I944) 54 YaLE L. J. $36,38 \mathrm{n} .7$. Statutes putting teeth into clauses to arbitrate future disputes have been adopted in such commercially important states, in addition to New York, as California, Connecticut, Louisiana, Massachusetts, Michigan, New Jersey, Ohio, Oregon, Pennsylvania, Wisconsin. See Professor Sturges' summary of the statutes of the various states governing arbitration in Annex I to Kelzor, Arbitration in Action (194I) $217 \mathrm{ff}$.

"Int. Ch. of Comis., International Commercial Arbitration-Practicai. Hints (i935) 8. 
greatest consequence are the New York Law of $1920^{\circ}$ and the Federal Arbitration Act of $1925 .{ }^{7}$ The New York Law is of particular significance because so much of the foreign trade of the country is done by merchants in New York, and therefore many arbitrations of international commercial disputes are handled in New York City. Other seaboard states have grown in importance during the past twenty years, and therefore their laws may well grow in weight as more trade flows through their ports.

The New York Arbitration Law provides that a written submission to arbitrate an existing controversy or an agreement to arbitrate future controversies "shall be valid, enforcible and irrevocable, save upon such grounds as exist at law or in equity for the revocation of any contract." Specific performance of the agreement to arbitrate can be compelled. ${ }^{2}$

The Federal Act of 1925 and most of the commercially important states in the United States have provisions similar to that of the New York Law in regard to the validity of the arbitration clause. ${ }^{10}$

It is also proper to note that courts in the United States, both federal and state, have not shown a disposition to compel arbitration in a foreign jurisdiction. That means that if an American national refuses to participate in an arbitration to be held in a foreign jurisdiction, even though he has agreed to do so in his contract of purchase or sale, courts in the United States are unlikely to compel such participation. ${ }^{11}$ And while some federal courts have stayed actions brought in contravention of an arbitration agreement to arbitrate in a foreign jurisdiction, ${ }^{12}$ other federal courts have issued decisions to the contrary and have permitted trial in the courts. ${ }^{13}$ Hence, when the defendant is located in these jurisdictions, the exporter and importer may be faced with the choice-not without risk-of proceeding with an arbitration without the participation of the defendant. Some courts might enforce the award and other courts would refuse to. This emphasizes the need of providing for arbitration under the rules and regulations of a tribunal such as the American Arbitration Association, whose rules, as previously stated, specifically provide for obtaining jurisdiction over a defendant outside of the state or country where the arbitration is to be held and in addition for the holding of the arbitra-

'N. Y. Civil Practice Act, $\$ 1448$ et seq.

743 Stat. 883 (1925), 9 U. S. C. (1940) \$§I-I5.

${ }^{8}$ N. Y. Civil. Practice Act, \$I 448 .

${ }^{\circ} I d$., $\$ 1450$.

${ }^{10}$ See stipra note 4.

${ }^{11}$ Application of Inter-ocean Food Products, 206 App. Div. 426, 201 N. Y. Supp. 536 (1923); In re California Packing Corp., I2I Misc. 212, 201 N. Y. Supp. 158 (1923). Insofar as these cases rest on the rationale that an award taken outside the state cannot be the basis for a judgment, their authority seems shaken by the Gilbert case, infra p. 823. It has been held in New Jersey, on the other hand, that the court can order arbitration outside the state, the parties having so agreed. California Lima Bean Growers' Ass'n v. Mankowitz, 9 N. J. Misc. 362, 154 Atl. 532 (193I).

${ }^{12}$ Danielson v. Entre Rios Rys. Co., 22 F. (2d) 326 (D. Md. 1927).

${ }^{13}$ The Silverbrook, 18 F. (2d) 144 (E. D. La: 1927), on court's interpretation of the federal Arbitration Act. 
tion even if the defendant does not appear..$^{13^{2}}$ In such cases, held under the rules and regulations of the American Arbitration Association, the courts are likely to enforce an award even if the defendant has not participated in the arbitration hearings. This is another example of the importance of an arbitration association or tribunal as against the informal type of arbitration to which too many foreign traders still agree in their contracts.

Third: Central and South American Republics and Canada.

a. At several Pan-American conferences commercial arbitration was discussed at length. Finally, at the Fourth Commercial Pan-American Conference in I93I, a resolution was adopted asking the Pan-American Union to make a study of the subject. In 1933 the Pan-American Union made a report to the Seventh International Conference of American States at Montevideo urging the adoption of uniform laws and procedures of arbitration among the American Hemisphere nations. But despite this report only Colombia, in the Law of $1938,{ }^{4}$ adopted a law as broad as the laws of England and the United States and some other European countries which would definitely uphold the validity of an arbitration clause even if it provided for arbitration in a foreign jurisdiction. While Brazil ratified the I923 Convention, there seems to be nothing in its law of 1939 or in its civil code which would give confidence in the upholding of the validity of an arbitration clause calling for arbitration in a foreign jurisdiction or for enforcement of the award itself.

In I940 a Treaty on International Procedural Law was signed by the Argentine Republic, Bolivia, Brazil, Colombia, Paraguay, Peru and Uruguay. ${ }^{15}$ It has not been ratified by any of the signatory powers so that at this time it is still without meaning or value. Although a merchant can properly assume the validity of an arbitration clause in a contract with European or United States merchants, he must rely upon the good will of those with whom he deals in Central and South America to arbitrate disputes rather than on the laws of those countries.

b. In Canada, eight of the provinces follow the English law which recognizes the validity of arbitration clauses, while the province of Quebec follows French law, which also recognizes somewhat limitedly the validity of these clauses. ${ }^{16}$

Wording of Clauses. In addition to having an understanding of just how the laws will affect them, it is important for the exporter and importer to understand how to word the arbitration clause that they use in their contracts. Careless or improper wording might cause the courts of some countries to declare the clause

132 Mulcahy v. Whitehill, 48 F. Supp. 917 (D. Mass. x943) (judgment entered by Federal District Court in Massachusetts upon a judgment entered in a New York State court, in conformity with New York law, upon an arbitration award made against a non-appearing defendant).

1" Law 2 of Fcb. 25, 1938, Diario Oficial No. 23727, March 11 , 1938, translated in (I945) I INT. ARB. J. 212 (International Arbitration Journal, since combined with Arbitration Journal).

${ }^{16}$ Segundo Congreso Sudamericano de Derecho Internacional Privado, Acta Final, Segunda Edcrón (Montevideo, I940) 4I; trans. in (1943) 37 AN. J. OF INT. L., Supp., II 8 and (I945) I INT. ARB. J. 209.

${ }^{10}$ Domke \& Kellor, Western Hemisphere Systems of Commercial Arbitration (1946) 6 Unrv. of TORONTO L. J. 307, 325-6. 
invalid despite the general provisions of the law upholding the validity of such clauses. And the highly important question whether jurisdiction can be obtained over a non-resident of the state or country in which the arbitration is to be held may frequently hinge on the wording of the arbitration clause. There are a great many associations active in the field of international commercial arbitration, but I have chosen as sample clauses those of the International Chamber of Commerce and of the American Arbitration Association.

The International Chamber or Commerce clause ${ }^{17}$ reads as follows:

"All disputes arising in connection with the present contract shall be finally settled under the rules of conciliation and arbitration of the International Chamber of Commerce by one or more arbitrators appointed in accordance with the rules."

The American Arbitration Association recommends various clauses to be used in contracts which come under its jurisdiction or under the jurisdiction of organizations which it sponsors such as the Inter-American Commercial Arbitration Commission and the Canadian-American Commercial Arbitration Commission. The American Arbitration Association clauses read as follows:

"Any controversy or claim arising out of or relating to this contract, or the breach thereof, shall be settled by arbitration, in accordance with the Rules, then obtaining, of the American Arbitration Association, and judgment upon the award rendered may be entered in any Court having jurisdiction thereof."18

"Any controversy or claim arising out of or relating to this contract or the breach thereof, shall be settled by arbitration, in accordance with the Rules, then obtaining, of the InterAmerican Commercial Arbitration Commission. This agreement shall be enforceable and judgment upon any award rendered by all or a majority of the arbitrators may be entered in any court having jurisdiction. The arbitration shall be held in $\ldots \ldots \ldots \ldots \ldots$ or wherever jurisdiction may be obtained over the parties."10

In some jurisdiction it is important that the arbitration clauses specifically provide for the extent of the powers of the arbiters. Some laws limit the arbiters to decisions based strictly on the commercial laws of the country in which the arbitration is held. Other arbitration laws allow the arbiters to decide cases on the merits without regard to the law. This aspect will be discussed in greater detail at a later point in the article, but is mentioned at this point so that the merchant bears in mind the possibility of having to include some reference to the powers of the arbiter in the abitration clause.

It is also well to include the clause in each contract of sale and purchase. It is unwise to attempt to provide for arbitration by general reference to some other written understanding between the parties or by reference to the contract being subject to the rules of a trade association which has arbitration rules and acts as an arbitral tribunal. Some courts have held that failure to include an arbitration

${ }^{17}$ INT. CH. of CoMm., op. cit. supra note 5.

${ }^{18}$ Rules and Regulations of American Arbitration Association.

${ }^{10}$ Rules and Regulations of Inter-American Commercial Arbitration Commission. 
clause in a specific contract indicated lack of intent on the part of the parties and therefore refused to uphold the validity of arbitration provided for in any general terms or reference. ${ }^{20}$

\section{B. Procedure}

When a dispute arises it is important that the parties know how to arrange for an arbitration and then how an arbitration is conducted. ${ }^{203}$ In regard to the selection. of a tribunal and place of arbitration there are generally two types of clauses. One clause specifies that the arbitration shall be held under the rules and regulations of a specific association. This may be one of the generic types of commercial or arbitration associations such as the International Chamber of Commerce, the American Arbitration Association or the London Court of Arbitration. Or the clause may provide for arbitration before a specific commodity or trade association such as the London Corn Association or the Rubber Trade Association of New York or any of a great many other similar groups. The clause will frequently specify the place in which the arbitration is to be held unless an association is mentioned that conducts arbitrations only in one place. That would fix the place of arbitration. In the case of the International Chamber of Commerce there is a different procedure which will be described later.

Another type of arbitration clause does not specify an association but states that each of the parties is to choose an arbiter and that the arbiters are to choose an umpire who will decide in the event that they disagree. Such clauses may or may not include designation of the place in which the arbitration is to be held. The disadvantage of this type of clause is that the procedure is left to the arbiters and umpire to act under the statutory law and that as laymen they may not know the law or the proper procedure which will enable the winner to secure a valid and enforcible award. Therefore the first type of clause which always specifies an association to act as the arbitration tribunal is the more satisfactory of the two. For, while it is true that in most countries arbitrators have wider latitude in regard to the rules of evidence, the principles of law, and the conduct of arbitration hearings than do judges in a court of law, it is also true that neglect of some procedural item or a disregard of some legal requirement may result in the court having to throw out an arbitration award which would otherwise be recognized and enforced as a judgment in favor of the winner.

The many associations, both general and specific, which conduct arbitration proceedings have issued their own rules. But these rules have all been prepared with a view to the laws of the countries in which the arbitrations are held by the issuing tribunal. And as both the American Arbitration Association and International Chamber of Commerce deal with arbitrations in many countries of the world, I am citing the essentials of their rules of procedure.

The International Chamber of Commerce provides for conciliation before arbi-

\footnotetext{
${ }^{20}$ Note, Incorporating Arbitration Clauses by Reference (r944) 8 UNIv. OF DET. L. J. 26.

20* See Braden, Sound Rules and Administration in Arbitration (1934) 83 U. OF PA. L. Rev. I89.
} 
tration. The American Arbitration Association has no provision for conciliation. The Inter-American Commercial Arbitration Commission which was set up under the auspices of the American Arbitration Association attempts conciliation before arbitration. Those tribunals that have rules for conciliation have set forth simple procedures by which committees of the organization attempt to bring the two parties together without resort to the judicial proceeding of arbitration. Either party to the contract may ask the tribunal to use its good offices in examining the facts of the case and in making friendly suggestions to both parties in the hope that a compromise can be effected. In the case of the International Chamber of Commerce the pre-war rules called upon each party to deposit Fr. Fr. 500 for the expenses of the Court of Arbitration in the conciliation proceedings.

Upon receipt of any written request and the necessary papers, documents and the deposit, the proper official of the International Chamber of Commerce informs the other party to the dispute through the National Committee of the International Chamber of Commerce in his country and invites the other party to accept the intervention of the International Chamber and to submit his side of the case. If both parties agree to accept the assistance of the International Chamber, two or more members of the Administration Commission of the International Chamber of Commerce and the Chairman of the Commission constitute a conciliation commission and examine all of the details pertinent to the dispute. The parties can appear in person, can employ counsel, or submit their statements in writing. After examination of written submission or oral hearings, the conciliation commission submits its suggestions for settlement. If both parties agree, a record of the statement is prepared by the commission and. the case is considered closed. If the parties do not agree, they are at liberty to submit their dispute to arbitration, or if they are not bound by an arbitration clause, they may of course appeal to the courts. Nothing that takes place before the conciliation commission in any way affects the legal rights of the parties to take further arbitration or court action. ${ }^{21}$

In regard to arbitration, the rules of both the International Chamber of Commerce and the American Arbitration Association provide substantially for the same procedural acts by the parties even though the wording may be somewhat different. ${ }^{22}$

I. Both provide for the agreement of the parties to abide by their rules in the event that the tribunal is specified in the arbitration clause.

2. Both outline the method by which either party can write to the tribunal and ask for arbitration. They specify the way in which such written demand is to be sent and the documents that must accompany the demand.

3. They outline what the tribunal will do upon receipt of the demand for arbitration in regard to notifying the defendant and what the defendant is obligated

${ }^{31}$ Rules of Conciliation \& Arbitration in Force as of January 1, 1940, of International Chamber of Commerce.

${ }^{22}$ Commercial Arbitration Rules of the American Arbitration Association as amended and in effect January $x, 1945$. 
to do in order to fulfill his contractual obligations in replying to the demand for arbitration and preparing for the arbitration.

4. The rules and regulations of both of these tribunals, as of all other tribunals, set forth the method in which the arbitrators are to be chosen. The American Arbitration Association has a large panel of many thousands of arbitrators throughout the United States. The Canadian-American Arbitration Commission and the Inter-American Commercial Arbitration Commission also have large panels in Canada and throughout Central and South American Republics. After both parties have completed the preliminaries prescribed by the rules of the American Arbitration Association, the Association selects from its panels about twenty names of those competent to deal with the issues of the specific case. These lists are sent to both parties. Each party eliminates those who are not acceptable. From those who are acceptable each party indicates its order of choice. The lists are returned to the American Arbitration Association which then selects from one to three arbiters, depending upon the wishes of the disputants, from those who are acceptable to both, conforming as nearly as possible to the expressed order of choice. If none on the preliminary list are acceptable to both parties, upon their request a further similar list will be prepared in an attempt to find arbitrators upon whom both sides can agree. If the second attempt fails, the association designates the arbitrator or arbitrators from its panel without further reference to the parties, and both parties are bound by this choice.

In the case of the International Chamber of Commerce, usually one arbitrator is selected to hear the case, although at the wish of the parties three arbitrators will be appointed. The International Chamber of Commerce does not have large panels from which a choice is made. Instead, the National Committees of the International Chamber nominate from time to time technical or legal experts who are available as arbitrators. If one arbitrator is to be appointed, the Court of Arbitration of the International Chamber names the arbitrator from a country other than the countries of which the parties are nationals. When three arbitrators are appointed, one is selected from the country of which each party is a national and the third is selected from a neutral country.

5. In the case of the American Arbitration Association, the place of the arbitration is usually in New York City unless some other part of the United States is specifically designated or agreed upon. If the parties fail to agree on a place, the Association designates it. In the case of the Inter-American Commercial Arbitration Commission both parties should provide for the place of arbitration at the time that the contract of sale or purchase is made and the arbitration clause is included. In the case of the International Chamber of Commerce arbitration takes place in the country and place decreed by the Court of Arbitration of the International Chamber unless the arbitration clause has fixed a place by agreement of both parties. ${ }^{23}$

\footnotetext{
${ }^{23}$ The rules of the American Arbitration Association (supra note 22) provide that the parties may use the method of each selecting their own arbitrator and still agree to abide by the rules of the Association. In that case the umpire will frequently be from the panel of arbitrators of the Association.
} 
6. The rules of both associations provide for the form in which each side is to submit its formal agreement to arbitrate and also a statement of its case. The rules also provide that the tribunal or the arbitrators fix the time and place for each hearing and that written notice will be sent by the tribunal clerk, who is an employee of the tribunal association, to both parties. The rules of both the American Arbitration Association and the International Chamber of Commerce permit the parties to appear in person and to be represented by counsel. If the parties wish, a stenographic record of all testimony will be taken at the expense of the parties. No figures are available as to the number of cases in which stenographic records of the proceedings have been taken. But from my observation this is not done in the usual case involving simple contract disputes.

7. As to the hearings, the rules provide the manner in which the witnesses are to be sworn in, the order of the proceedings, the way in which exhibits are to be submitted, and the examination of witnesses. All of these procedural matters, which may seem to be useless red tape to the average exporter and importer, are necessary. Courts are more likely to uphold an arbitration award if matters of form are cared for and if correct procedure is followed. They are simply and clearly set forth in the two documents cited as references. These pamphlets should be carefully studied by those whose contracts include arbitration clauses.

As a matter of fact, some merchants conduct their own cases from start to finish without employing counsel, although the records of the American Arbitration Association show that these are in the minority.

8. After the hearings have been concluded, the arbitrators render their award. Although officers on the staff of the tribunals may not participate and are not even present at the deliberations of the arbitrators, they are helpful to the arbitrators in the preparation of the awards so that they are issued in a form which will assure enforcement by the courts of those countries which have adequate legal provisions therefor.

9. The rules and regulations of both make reference to the costs and fees. The American Arbitration Association has a fixed schedule based on the amount in volved. The Court of Arbitration of the International Chamber of Commerce fixes the fees to be paid by the parties and also decides as to whether the costs should be paid by the winner or loser. Those who act as arbitrators for the American Arbitration Association usually receive no compensation although in special cases the Association may fix a fee with the agreement of the parties. In the case of the International Chamber of Commerce whatever fees are paid to the arbitrators are fixed by its Court.

\section{Powers of Arbiters}

In many jurisdictions there is still doubt whether or not the decisions of the arbitrators are final as to the merits of the case and will be enforced by the courts or whether the courts will rehear the cases, examine into the merits and issue decisions of their own which will supersede and perhaps overrule the decisions of the 
arbitrators. This has its historic background in the age-old struggle of many courts to maintain their supremacy against any outside groups making decisions that would be legally binding and thereby impinging on the jurisdiction of the judges.

There is also the problem as to whether or not an arbitrator must base his decisions strictly on the legal considerations involved in the case or if an arbitrator may decide a case according to his view of the intent of the parties and what would be fair to both regardless of legal requirements or established principles of law.

Lawyers are not fully agreed on the two problems of the extent of the power of arbitrators and the enforcement of awards. This section deals with the former. In my opinion-as a layman-most commercial arbitration cases involve certain facts and intents and the equities arising therefrom. If these were cases tried in a court of law, a good many of them would be confined to questions that a jury would decide. And I think that even though there are businessmen who are always looking for an out in a non-profitable contract, most foreign traders in those countries that have had international commerce for a long time wish only a fair decision based on the merits of the case without regard to some of the technical principles of contract and sales law. I also think that this attitude will grow in countries which are still young in international trade and which are likely to grow and expand in that field over the next few decades. Then, too, businessmen want mostly to escape the costs and delays of prosecuting cases through the courts of law as well as the risks of decisions by juries that cannot possibly have sufficient background to enable them to review the facts intelligently.

The power accorded to arbitrators by law is not the same in all countries. Generally speaking, arbitrators do not and should not ignore the commercial law, both statutory and decisional, of the countries in which they conduct arbitrations. But the laws give arbitrators greater discretion in some countries than in others. In still other countries both of the parties can by agreement, either in the arbitration clause or at the time they sign the submission to arbitration, give the arbitrators the wide latitude of deciding a case solely on its merits, as they see the merits, without regard to the law and perhaps even contrary to a strict interpretation of the law.

Dr. E. J. Cohn divides the groups of laws defining the powers of the arbitrators into three. ${ }^{24}$

I. The Latin group: In countries such as France, Belgium, Italy, some South American and Central American Republics, Portugal, and a number of Swiss cantons, the arbitral tribunal (the arbitrators) is bound to observe the rules of law. Appeals can be made to the courts which will quash an arbitration award if the arbitrators have violated the rules of law in arriving at their award. The laws of these countries are also strict in regard to the proceedings by which an arbitration is conducted, which gives added emphasis to the importance of having the arbitration conducted by one of the organizations that can guide both arbitrators and parties in meeting legal requirements.

${ }^{21}$ Cohn, Commercial Arbitration and the Rules of Law-A Comparative Study (I94I) 4 UNiv. of ToRonto L. J. I, 2-7. 
But at the same time the laws of these countries allow the parties to agree, either in the contract or in the submission thereafter, that the arbitrators may decide without regard to the rules of law. In these countries, however, there is a specific distinction made between those who are called arbitrators and must abide by the rules of law and those who may disregard the law, who are called "amiables compositeurs." In some South American countries the "amiables compositeurs" are called "de facto" arbitrators, whereas those that are bound by the rules of law are called "de jure."

It is probably better to provide in the arbitration clause in the original sales contract that the arbitrators may act "as amiables compositeurs," rather than to have them bound by the rules of law in the original contract with the hope that afterwards both parties will agree in the submission to make the arbiters "amiables compositeurs." The party with a weak case will undoubtedly refuse this enlargement of powers.

2. In a second group, "the arbitrator is free to decide even contrary to the ordinary laws of the land." ${ }^{25}$ In most countries that give the arbitrator such broad powers, there is no explicit law conferring these powers on him. But the laws make no provision for any appeal to the courts or give any other remedy in the event that the arbitral award is contrary to the law. Hence, by default of legal provisions to the contrary and by the broad provisions of the law pertaining to the enforcement of arbitral awards, the arbitrators have in effect the powers of "amiables compositeurs" and may decide the cases entirely on their merits without having to consider the commercial laws of the country in which the arbitration is held. There is, however, one important legal distinction between the powers of the "amiables compositeurs" as described in I and the arbitrators in 2. "Amiables compositeurs" are actually freed from having to consider the rules of law. The arbitrators, as described in 2, are not explicitly freed by law from having to consider the rules of law but are not bound to consider the rules of law because of the absence of laws so binding them and because of the laws pertaining to the enforcement of arbitration awards. The more important European countries, whose legal code allows the arbitrators to have such broad powers, are Scotland, Germany, Austria, Norway, Poland and Denmark. This is also true in Japan as well as in the Federal Arbitration Statute of $x 925$ in the United States and the statutes of many individual states, including New York, whose importance in international commercial arbitration has already been mentioned.

3. In his third group Dr. Cohn includes England, some of the British Dominions and some American states in which the arbitrators must observe the rules of law unless the parties by agreement have absolved them from this duty. Under English law; which is followed by some of its Dominions as well as a few American states, the parties to the arbitration may ask the courts for a legal opinion on any point while the arbitrators are holding their hearings. By their right to compel the

${ }^{2 s} I d$. at 4 . 
arbitrators to submit a case to the courts and by the compulsion on the arbitrators to follow the decision of the courts in regard to the law, the parties can make the rules of law a binding guide upon the arbitrators as long as no award has yet been made. In practice this still leaves the arbitrators great powers in deciding a case on its merits while enabling the parties to prevent an arbitrator from completely disregarding the rules of law through their right to ask the courts for a ruling during the conduct of the proceedings. The laws pertaining to the "amiables compositeurs" do not permit any appeal to the courts for a legal ruling at any time so that arbitrators in such proceedings could even reach an award which would be contrary to the law of the land and there would be no relief accorded to the loser.

As a layman who has represented his company in arbitration proceedings as well as having been a commercial arbitrator in a good many cases, I think that the third group of laws probably gives the greatest protection to both parties. But, of chief importance, is the knowledge of the merchant as to what the powers of the arbitrators are in the jurisdiction in which he agrees to arbitrate so that when he issues a contract of sale or accepts a contract of purchase, he knows what the powers of an arbitrator will be in the event that he and his fellow merchant disagree.

\section{Enforcement of Awards}

It is, of course, useless to sign a contract with an arbitration clause if one party can afterwards refuse to arbitrate and get away with it. Also, an arbitration proceeding and award are of no value if the loser can successfully refuse to obey the award. This does not mean that there are not a great number of companies that would abide by arbitration awards against them even if there were no laws compelling them to do so. But the whole strength of commercial arbitration as a method of settling international trade disputes is limited if the loser can welch successfully. And the courts have so well and so jealously guarded their prerogatives as the final determinants of the rights of parties in dispute that the situation affecting the exporter and importer who agree to international commercial arbitration is not uniformly clear and simple. At best only a survey can be made indicating what the merchant can probably expect if he wins an arbitration award and has to refer to the courts to enforce that award without having to retry the case before judge and jury.

I. After the Geneva Protocol of I923, upholding the validity of arbitration clauses, there was another convention in Geneva in 1927 at which it was agreed that the parties signatory thereto would enforce awards against their own nationals, that were made in their own territory or in the territories of other states signatory to the Convention. Some of the signatory nations made their ratification of the Convention subject to the fulfillment of certain conditions of form. But in the main the intent was that the signatory powers would recognize arbitrations made in each other's jurisdictions. ${ }^{26}$

It is important to note that neither the United States nor any of the other West-

${ }^{30}$ INT. Cr. OF CoMrs., Brochure No. 9 I (1936). 
ern hemisphere nations participated in the Convention or afterwards ratified it. It is also important to know that in some countries the "conditions of form" are sufficiently complicated to raise grave doubt as to whether or not an arbitration award would be enforced by the courts. Of all of the countries that ratified the Geneva Convention of 1927, England probably has the most liberal laws toward enforcing arbitration awards without retrying the cases in the courts. ${ }^{27}$ There are a few restrictive conditions in English law which in practice do not affect a properly handled arbitration case and properly drawn award. In English law:

(a) Arbitration held in a foreign jurisdiction will be considered valid if the subject matter is one that can be arbitrated under English law.

(b) English law will uphold an arbitration award if the award would be upheld in the country in which it was made.

(c) The award will be upheld if all of the procedures initiating the arbitration, holding the hearings and writing the award were correct.

(d) The award will be upheld unless there is ground for assuming the misconduct of an arbitrator or an error of law appearing on the face of the award.

Point (d) is of particular significance and will be discussed in greater detail later.

In Belgium if an arbitration award makes specific reference to the Geneva Convention, the Belgian courts are likely to give it added weight in their enforcement of the award. ${ }^{28}$

The Swiss courts will enforce awards against their nationals in arbitrations held in France and in Spain as Switzerland has a treaty with France and with Spain pertaining to the mutual enforcement of civil judgments. Arbitrations held in others of the ratifying countries to the Geneva Convention are not sure of being upheld by Swiss courts as Switzerland does not have similar treaties with them and the Geneva Convention is therefore not observed. ${ }^{20}$

In France the courts were for years hostile to enforcing commercial arbitration awards. Even after the 1927 Geneva Convention the courts did not materially change so that merchants could not be certain as to what would happen if a French loser refused to live up to an award. But latterly the French courts have tended to uphold arbitration awards in foreign jurisdictions unless the subject matter of the arbitration was one that could not legally be arbitrated under French law, such as matrimonial differences or disputes between parents and children. But as these do not come under the heading of international commercial disagreements, the exporter and importer can assume the probability that the French courts will uphold an arbitration award made in a foreign jurisdiction. ${ }^{30}$

In Holland the courts customarily enforce arbitration awards if not contrary

${ }^{27}$ Cohn, loc. cit. supra note 24; Macassey, The London Court of Arbitration (1945) I INr. ARn. J. 180,188 f.

${ }^{28}$ INt. Ch. of Comm., Brochure No. 88 (1934).

${ }^{29}$ INT. Ch. OF Comm., Brochure No. 6I (1927).

${ }^{30}$ Domke, Arbitral Clauses and Awards; Recent Developnents in French Latu (1943) 17 TULANE L. REv. $447,455$. 
to the morals of the country and if the arbitration has been held in one of the countries that ratified the Geneva Convention. ${ }^{31}$

Also, in the countries that ratified the Geneva Convention the courts generally would be likely to upset an arbitration award if there is evidence of dishonesty on the part of the arbitrators or if the award is contrary to the morals or public policy of the country in which the award is to be enforced. There is also the problem of unarbitrable material, such as the two observations relating to France and such examples as cases involving gambling, black market operations or smuggling.

Hence the merchant should understand that if he enters into a contract which involves dealings outside of the law or of public policy, the courts may well and properly refuse to uphold an arbitration award even though the two parties had previously agreed to settle their differences by arbitration. Assuredly that is as it should be.

2. In the United States, Gilbert v. Burnstine, decided by the highest New York court in $\mathrm{r} 93 \mathrm{I}$, is the foremost authority for the enforcement in this country of arbitration awards made in foreign countries. ${ }^{32}$ In the Gilbert case, the award was rendered by a London tribunal after notice of the arbitration had been served on the defendant in New York. The defendant refused to appear before the tribunal in London and did not participate in the arbitration. Nonetheless, the New York court held that the award would be enforceable in New York if the arbitration had been held in conformance with the arbitration law of England.

It is important to note that the Gilbert case conditioned the enforcement here of foreign arbitration awards on the proper acquisition by the foreign arbitration tribunal of jurisdiction over the non-English defendant. If the foreign arbitration tribunal does not acquire proper jurisdiction over the American national defendant, then it is entirely possible that the American defendant could successfully defend an action in the courts in this country on the award granted by the foreign tribunal. But it is simple for the foreign tribunal to acquire jurisdiction over the American national as a properly drawn arbitration clause will provide for the arbitration tribunal, the place in which the arbitration is to be held and that the American resident submits, by signing the contract containing the arbitration clause, to the jurisdiction of the foreign arbitration tribunal. Under those circumstances the award will probably be enforced in almost all important international trading states in the United States. The Gilbert case and subsequent cases which have followed it have probably done more in the United States for the enforcement of arbitration awards rendered by foreign arbitration tribunals than the Geneva Convention of 1927 did for the states which ratified it. ${ }^{33}$

3. Among the Central and South American Republics there are no laws en-

sx Letter from the Hall Trading Corporation, Rotterdam, to the author, quoting the information of counsel.

${ }^{32}$ Gilbert v. Burnstine, 255 N. Y. 348, I74 N. E. 706 (x93I).

${ }^{33}$ Domke \& Kellor, supra note 16; Note, Enforcenent of British Awards by New York Couts (1945) I INT. ARB. J. 66. 
forcing arbitration awards made in foreign jurisdictions with the exception of the 1938 law in Colombia. Despite the Treaty of International Procedural Law at Montevideo in 1940, to which reference has already been made, the signatory states have not passed the necessary legislation. And most of the Central and South American Republics did not participate in the Montevideo Conference resulting in that treaty. They, too, have no arbitration enforcing laws.

The Conference specifically recommended the enactment of legislation to enforce arbitral awards made in signatory states. And it is to be regretted that no action has been taken despite the expressions of good-will in this 'resolution and despite the active work of the Inter-American Commercial Arbitration Commission. ${ }^{34}$

Letters have been received from attorneys in Bolivia, Brazil and Peru expressing the opinion that the courts might enforce a foreign arbitration award, but at the same time explaining that there is such great uncertainty that businessmen cannot count upon such court action.

4. There is no Dominion statute in Canada. In eight of the provinces there are provincial laws modelled along the lines of the English Law of 1934, and the law of Quebec follows the French law. Therefore a merchant can conclude with a high degree of safety that an arbitration award made outside of Canada will be upheld by Canadian courts.

A review of the situation, therefore, indicates that exporters and importers have to rely on the good-will of the losers or upon the pressures of business associations and trade customs for the enforcement of arbitral awards in most countries. The law and courts giving greatest assurance of enforcement are in England and the United States. This is not a very satisfactory situation although the meager statistics that have been made available to me indicate a good record of compliance. Because of the war a good many associations have either failed to reply to questionnaires or have not had access to their old records.

The International Chamber of Commerce reports that 87 percent of the awards of which they have any knowledge were paid by the losers. ${ }^{35}$ Most of these were cases arbitrated in European countries.

American and United Kingdom records are also satisfactory, particularly since the English Law of 1934 and the case of Gilbert v. Burnstine in New York.

The laws of Central and South American Republics are definitely inadequate, and the record of those whose contracts have contained informal arbitration clauses has been none too good. But the Inter-American Commercial Arbitration Commission has done and is doing a good educational job, and its recent report indicates much progress. In its First War Period Report it cites three hundred and sixteen cases that came within its purview during $1942-433^{36}$ Of these, one hundred and thirty-two cases were settled by negotiation by the staff of the Commission. One hundred and nine cases were withdrawn or settled without help from the

34 (1945) I INr. ARB. J. 209; Domke \& Kellor, stpra note 16 , at 315.

${ }^{8 x}$ INT. CH. OF CoMm., op. cit. supra note 5 .

ao Inter-American Comm. Arb. Comm., First War Period Refort. 
Commission. Seventy-five were still unsettled when the report was issued. Only six came to formal arbitration.

While today there is every reason for international traders to agree to arbitration either in England or in the United States, there would seem to be little reason for the nationals of either of these countries to feel secure if their contracts of sale or purchase call for arbitration elsewhere in the American hemisphere or in a good many European and Far Eastern countries. A few European countries approximate the security that English and American law give. But there are far greater areas of insecurity in which enforcing legislation is needed.

If exporters and importers conclude that commercial arbitration is of advantage to them, they have much to do through arbitration associations and through their commodity and trade associations to obtain legislation needed for the enforcement of arbitration awards made in foreign jurisdictions.

\section{Arbitration Tribunals}

There are two types of associations that have arbitration tribunals to settle international commercial disputes. First, there are a number of commodity associations, trade associations and local chambers of commerce that are active in arbitration work. Second, there are associations organized solely for arbitrations and which handle all types of disputes, including international commercial cases. (I class the International Chamber of Commerce with this second type even though arbitration is only one of the many functions that it performs for the international merchant.)

A. Probably the principal commodity associations in the field of international commercial arbitration are those in England. In the pre-war period, the London Corn Trade Association is reported to have handled about 20,000 cases annually, the Incorporated Oil Seed Corporation about 7,000 and the London Jute Association about $1,000 .{ }^{37}$ In addition to these, there are the London Fur Trade Association, Inc., the Coffee Trade Federation, consisting of three different coffee groups, the London Spice Trade Association, the London Rubber Trade Association, the British Wool Federation, the General Produce Brokers' Association of London, the Hide Shippers' and Agents' Association, the Liverpool Cotton Exchange and many others. $^{38}$

Britain's pre-eminence in the field of international commercial arbitration is undoubtedly due to the fact that Britain has for so many centuries been the leader among the foreign trading nations of the world. Prior to World War I a great deal of buying and selling of goods moving in international commerce was handled by merchants in London even though the goods were non-British in origin and were shipped to non-Empire destinations. The trading importance of London as a world center helped English commodity and trade associations become the focal points of establishing trade customs and of arbitrating international commercial disputes. With the tremendous amount of buying and selling through London dealers

\footnotetext{
${ }^{37}$ Note, London Trade Associations and Commodity Exchanges (I945) I INT. ARB. J. 202.

39 Ibid.
} 
as a basis, English trade associations drew within their orbit of influence sellers and buyers in other markets of the world who would agree in their contracts of sale and purchase to arbitrate their differences before the English commodity association or trade association relating to their product.

In addition to commodity and trade associations there are some local chambers of commerce in England which have been active in the field of international commercial arbitration because the centers in which they have been located were for many years the leading world producers of certain goods. Among these are the Manchester Chamber of Commerce and the Bradford Chamber of Commerce. Manchester dominated the cotton cloth market and Bradford the woolen cloth market until the post World War I period. ${ }^{39}$

There are some similar organizations in various parts of continental Europe, but because of the war I have found it impossible to obtain information about those which were active in the field of international commercial arbitration during the last two decades. They have not been as important as the English associations.

Although there are a great number of commodity and industry associations in the United States, few have been active in the field of international commercial arbitration. A great many have rules and regulations for the arbitration of domestic disputes among their members, and many of these obtained the help of the American Arbitration Association in the writing of their rules and regulations. A few months ago I sent more than one hundred and fifty questionnaires to trade and industry associations in the United States whose members are active in export and import trade. Of those that answered, few have rules and regulations covering arbitration of disputes between their members or between their members and foreign nationals to whom they export or from whom they buy for import. And of the few who have rules, only eight have had actual experience in the handling of arbitration cases. Of these, four had no statistical records. Of the other four, the Rubber Trade Association was the most active with about seventeen hundred cases, many of which involved disputes between the American importers and foreign exporters. Their records indicate that the losers complied with the awards in every case. The other three together had about one hundred cases, of which there was an incomplete record as to what happened.

It is also interesting to observe that national associations in the United States such as the National Foreign Trade Council and the National Council of American Importers have no rules and regulations for arbitration. They refer their members either to specific commodity and trade associations or more usually to the American Arbitration Association. Also, the Chamber of Commerce of the United States is not active in the field of commercial arbitration, national or international.

Of many local chambers of commerce, few are interested in foreign trade, and of those few only the New York State Chamber of Commerce is active in arbitra-

s9 Kellor \& Domke, Arbitration in International Controversy (1945) 54. 
tion. The New York State Chamber was one of the pioneers in the field of commercial arbitration.

It is important to know about the English commodity associations as many exporters and importers who buy and sell in the markets of the world will find that their contracts include an arbitration clause stipulating one of the English associations as the arbitration tribunal. And it is interesting to observe that the English commodity associations such as those referred to have had more arbitration cases in a year than international groups such as the American Arbitration Association and the International Chamber of Commerce have had in this field during the entire course of their existence.

B. In this group belong those associations or arbitration tribunals which either have been organized solely for arbitration or which are international in their operations even though arbitration is only one of their functions. Whereas commodity associations handle international arbitration cases, they are located in only one place and all disputes must be referred to them at that place. On the other hand, the International Chamber of Commerce arranges for arbitrations to be held in any country of the world, and the London Court of Arbitration, while located in London, is organized solely for arbitration. The American Arbitration Association is also organized solely for arbitration, and while located in the United States, has affiliated with it the Inter-American Commercial Arbitration Commission and the Canadian-American Commercial Arbitration Commission and also has reciprocal arrangements with associations in other countries.

r. The oldest of this type of arbitration tribunal is the London Court of Arbitration which was founded in $1892 .{ }^{40}$ It is a joint committee of the London City Corporation and the London Chamber of Commerce. Although originally organized to settle commercial disputes, it is today a tribunal for all kinds of disputes that can be legally arbitrated in London. The joint committee is called the Court and consists of twenty-four members appointed by the City Corporation and the Chamber of Commerce. It is the committee of control and does not itself sit as a tribunal. It appoints arbitrators and umpires, selecting them from a panel of experts who are authoritative in the field of the dispute. Needless to say, the panel of experts has been chosen with great care as to the integrity and impartiality of its members as well as their technical competence. The I928 rules of the Court were amended to conform with the English Arbitration Act of 1934 and so comply with all of the provisions of English law. Although individual commodity and trade associations, such as those previously referred to, have their own rules and regulations, many have modelled them on the rules of the London Court. The London Court prefers to appoint one arbiter although it will appoint three at the request of the parties.

During the years of its existence the court has settled disputes between British nationals and the nationals of many European countries, the Union of Soviet So-

${ }^{\circ 0}$ Macassey, loc. cit. stupra note 27. 
cialist Republics, the United States, Argentina and the Far East. These cases dealt not only with many commercial disputes covering a wide range of commodities but also with cases involving insurance companies, manufacturers of different types of goods, building constructors, and other business relationships. ${ }^{14}$

2. World War I did much to change the channels of foreign trade. Goods from the Far East that had been shipped to Europe and then trans-shipped to the United States were shipped direct as new steamship lines and conferences were established. The dollar became a more widely used currency in foreign trade than it had been prior to World War I when many exports from the United States and imports into the United States had been sold and bought in sterling even though the trade was done with non-British Empire nations. In the early 20's, much foreign trade was done in Holland guilders, French francs, Swiss francs, and other currencies, until there was such widespread currency deflation and the pound sterling again became the common denominator for so much of the foreign trade of the world. But the pound sterling never achieved its full pre-World War I importance and there were other factors in international trade which made many of the lesser countries more active in matters pertaining to trade customs and techniques.

The creation of the International Chamber of Commerce was one indication of a growing interest by the United States and other countries in taking an active part in international business policies. It was founded in 1920 by business groups in Belgium, Italy, France, England and the United States. Between 1920 and 1939 it grew until it was represented in forty-six countries, of which thirty-four had established national committees. There was an American division which has recently been reorganized as the United States Associates of the International Chamber of Commerce with an office in New York City.

During the nineteen years of its existence before the outbreak of World War II, it was active in all fields of international trade such as finance, transport, trade customs, dealing with governmental authorities and with the League of Nations. Until 1939 it maintained its headquarters in Paris. It then moved partly to Stockholm. With the war over, it is reorganizing and making plans to be even more active in the future than in the past. A number of national committees are already functioning. There have been some meetings in London and further sessions are planned for this summer. Among them will be a session dealing with international commercial arbitration in which the American Arbitration Association will participate.

In I92I a committee was appointed on international commercial arbitration to establish a system which would have the acceptance of foreign traders in all countries and which would have legal recognition from governments pertaining to the validity of arbitration clauses, the appointment of arbitrators, the powers of arbitrators and enforcement of awards. Specifically, the committee had to consider first the needs and desires of those actively engaged in international commerce and

${ }^{41}$ Id. at 192. 
second what could be done toward obtaining uniform legislation on those points discussed in Part II.

In I922 a court of arbitration of the Chamber was established and rules of arbitration were announced. The court began active work in 1923. At the same time a permanent committee on arbitration was appointed to work with governments in order to obtain the needed legislation. The committee did much toward accomplishing the Geneva Protocol of 1923 and the Geneva Convention of 1927. But as has been explained, these are limited in their effect and there is still a great deal to be done before a merchant can assume the recognition by law of an arbitration award.

The court itself does not arbitrate. It appoints the arbitrators as has been described in Part II, Section B. There is no formal panel of arbitrators, but the court always tries to obtain experts who can deal adequately and fairly with the dispute at hand.

The rules and regulations are changed constantly with changing commercial conditions and with new legislation.

The 1939 report of the court stated that something over seven hundred cases had been handled since its establishment in I923. One hundred and twenty were settled by conciliation. One hundred and twenty-three were settled outside of the court on the intervention of the Chamber, but without any active part by the Chamber or the court. In thirteen cases the court appointed an umpire after the parties chose the arbitrators, and there is no record of the outcome. Seventy-seven cases were settled by arbitral award. Three hundred and thirty-two cases were dropped in the early years as the contracts had not included a valid arbitration clause and so an arbitration award could not have been made effective. Thirty-seven cases were pending in $1939 .{ }^{42}$

The International Chamber of Commerce has worked out an arrangement with the American Arbitration Association as a result of which cases brought before its court of arbitration for hearing in the United States are referred to the American Arbitration Association and conducted under the rules and regulations of the latter.

3. (a) The American Arbitration Association was organized in 1926 as a consolidation of the Arbitration Society of America and the Arbitration Foundation. Commercial arbitration in the United States began its substantial growth with the enactment of the New York State Law of rg20, the Federal Act of 1925 and the establishment of the American Arbitration Association. It is a non-profit making and non-partisan membership association which is authorized under its charter to maintain arbitration panels and administer arbitration tribunals. It has provided facilities for arbitration throughout the United States and its cases are noncommercial as well as commercial. Its panels now number more than ten thousand arbitrators in more than fifteen hundred cities. Its rules and regulations meet

12 Address of John P. Gregg, Executive Director, U. S. Associates, Int. Ch. of Comm., on Commercial Arbitration through the International Chamber of Commerce Court of Arbitration (Boston, June, 1945). 
American legal requirements and have served as a model for a good number of specific commodity and industry associations. ${ }^{43}$ Although no statistical record of the number of international commercial cases held under its jurisdiction is available, there has been an increasing number as more and more American merchants have provided for arbitration in the United States in their contracts of sale and purchase. And during the war British, French and Dutch purchasing commissions, as well as the Amtorg Trading Corporation, which represented Russian trade interests, provided for arbitration of contract disputes with American nationals under the jurisdiction of this association.

In addition to acting as an important tribunal in the United States, the American Arbitration Association has been active in the field of furthering international commercial arbitration in other centers. It now has reciprocal arrangements with many foreign organizations. It made an arrangement with the American Chamber of Commerce in London in 1934 to recommend the use of a clause under which the rules of the Chamber will be used when the arbitration is to be held in London and the rules of the Association when it is to be held in the United States. ${ }^{44}$ It has a similar agreement with the Manchester Chamber of Commerce, although this is limited to commodities in which the Manchester Chamber is primarily interested. ${ }^{45^{\circ}}$ Its arrangement with the International Chamber of Commerce has already been described. It is now working on a similar agreement with the Chamber of Commerce in the Philippine Islands in Manila, another agreement with a delegation representing the Chinese government, and is planning a further extension of such arrangements. ${ }^{46}$

3. (b) The Inter-American Commercial Arbitration Commission, to which reference has already been made, has its headquarters in New York with the American Arbitration Association and is guided by it in matters pertaining to organization and administration. Actually the members of the Commission represent all of the twenty-one American republics, and nominations for membership on the Commission are approved by the Pan-American Union. ${ }^{47}$ National Committees appointed in each republic conduct the practical operations of the Commission. These national committees organize panels of arbitrators, educate business and professional men in the use of arbitration and work toward obtaining legislation which will uphold the validity of arbitration clauses and enforce arbitral awards. As has already been stated, the Commission has made great progress in the field of education and is daily obtaining wider acceptance of commercial arbitration among the Western hemisphere nations and is also doing much to obtain compliance with arbitration

${ }^{43}$ Domke \& Kellor, supra note 16 , at 319.

"Id. at $32 x$.

4 Ibid.

${ }^{40}$ Note, United States-Philippine Commercial Arbitration Service (1945) I INT. ARB. J. I14.

${ }^{47}$ Domke \& Kellor, supra note 16, at $308 \mathrm{ff}$.; Rules and Regulations of the Inter-American Commercial Arbitration Commission. 
awards even though the laws of all but the United States and Canada will not enforce them if issued in a foreign jurisdiction. ${ }^{48}$

The Commission issues monthly reports to its members citing examples of the cases that have been held in its jurisdiction and containing other information that is interesting and educational and which will do much to teach businessmen about arbitration and what they must do if they would arbitrate properly. But good-will alone is not a sufficient safety factor when prices turn downward and the unscrupulous merchant refuses to live up to his contract. For that reason the Commission must continue to work toward improving existing legislation.

3. (c) Canadian-American. In I943 an agreement was concluded between the American Arbitration Association and the Canadian Chamber of Commerce, as a result of which both groups set up the Canadian-American Commercial Arbitration Commission. The Commission does not arbitrate cases, but each section of the Commission-Canadian and American-maintains panels of arbitrators in its respective jurisdiction. The Commission has adopted rules of procedure similar in content to those rules already described. Its headquarters in the United States are at the American Arbitration Association in New York and in Canada at the Canadian Chamber of Commerce in Montreal. ${ }^{49}$

In addition to spearheading the development of the Inter-American and the Canadian-American Commercial Arbitration Commissions, the American Arbitration Association has been working toward the coordination and synchronization of all three systems into a combined Western hemisphere system. ${ }^{50}$ An arbitration clause has been worked out to be included in all contracts between nationals of any of the American hemisphere republics and Canada. It would provide that an arbitration to be held in the United States would be under the jurisdiction of the American Arbitration Association; in the Latin-American republics, under the rules of the Inter-American Commercial Arbitration Commission; and in the Dominion of Canada under the rules of the Canadian-American Arbitration Commission. Whereas this would give validity to the arbitration clause itself and would do much to permit the use of arbitration among those who, of their own accord, are willing to abide by decisions made against them, it must again be borne in mind that only the laws of the United States and Canada in the Western hemisphere give assurance to the winner that he can enforce an arbitration award in the courts. Hence, the combined system cannot really become effective until the Central and South American republics improve their legislation in this regard.

\section{Conclusion}

From the analysis that has been made it is obvious that there is need for substantial improvement in the field of international commercial arbitration. There

\footnotetext{
${ }^{48}$ Some laws will enforce an arbitration award if the arbitration is held within their own jurisdiction cven though a foreign national is a party in the case. But even this is not uniform among the Central and South American Republics.

${ }^{\circ}$ Domke \& Kellor, supra note 16 , at 325 .

${ }^{50}$ Id. at 328 .
} 
are a great many legal problems that press for solution, and on the operating level there is also much progress to be made. Wider and more thorough knowledge of arbitration techniques is essential if arbitration is to grow in use among exporters and importers. In this there is great promise in the post-war activities of the American Arbitration Association and the International Chamber of Commerce.

In its infancy arbitration was attacked most vigorously because "it ousted the courts of jurisdiction." But, although many courts are still hostile to commercial arbitration, the purely legalistic and jurisdictional attacks of the courts have lessened and current criticisms are more realistic and more substantial. Mr. Philip G. Phillips expressed the view ten years ago that the freedom of arbitrators in jurisdictions such as New York to ignore principles of law introduced an element of uncertainty in business relations and made impossible the predictability of the legal consequences of business acts. ${ }^{51}$ It was his contention that the obligation of the courts to follow settled legal principles gave businessmen the assurance that they needed in making spot, daily decisions. But it has been my observation and experience that although arbitrators in New York have great freedom in ignoring settled principles of law, in practice they do not act arbitrarily or with caprice. On the other hand they give careful attention to any legal citations that are made during the course of an arbitration, and they are keenly aware of statute law and court decisions affecting the controversy before them. When they depart from the settled law it is only in the interest of substantial justice applying to the specific case with which they are dealing.

And furthermore, businessmen frequently prefer arbitration based on facts as interpreted by arbitrators to the uncertainty of the way in which the courts will appraise commercial facts, particularly in the field of international trade. More often than not the services of businessmen who have an understanding of the techniques and practices of international trade will result in more equitable decisions than cases that come before the courts, whose decisions must be based on the determination of facts either by courts or juries who cannot be conversant with mercantile problems and customs.

In his article on business arbitration ${ }^{52}$ Dr. Heinrich Kronstein makes several points of opposition in principle to commercial arbitration. A number of these points are applicable particularly to international commercial arbitration. Summing up his objections, they are based on his conclusions that commercial arbitration helps rule by big business to the detriment of both the public and smaller independent business.

In support of his thesis, Dr. Kronstein lists a number of examples such as the use of arbitration to further cartel practices, the use of arbitration by exchanges as a result of which a member can well be expelled for refusal to abide by an arbitration award and thereby forced out of business, and similar use of arbitration by

${ }^{51}$ Phillips, A Lawyer's Approach to Commercial Arbitration (1934) 44 Y ALE L. J. 31 .

${ }^{62}$ Kronstein, stupra note 4 . 
commodity associations that would blacklist a loser who failed to comply with an arbitration award. He further contends that there are grave dangers of permitting arbitration tribunals to decide on the validity of contracts, to rule in matters pertaining to patents and trade marks and to set up an extra-legal compulsion from which there is no appeal or recourse to the courts.

Although a number of these points are supported by the examples that Dr. Kronstein gives, I do not think that opposition to international commercial arbitration, as an advantageous method of settling commercial disputes among foreign traders, is the necessary and irrevocable conclusion. Dr. Kronstein's argument does pose a number of problems, but I think that these problems can be solved as laws are changed to meet the needs of arbitration discussed supra in Part II of this paper. It should be entirely possible to incorporate in such legislation provisions to prevent the perversion of arbitration procedures for the selfish and improper ends of any business group.

At the present time there is a greater demand for merchandise than manufacturers and merchants can possibly supply. It is therefore an appropriate time to plan for the future when goods will again be plentiful and when, in a period of surpluses and declining markets, commercial disputes will grow in numbers and in bitterness. Exporters and importers who favor arbitration as the method of settling the disagreements should now work with the American Arbitration Association and the International Chamber of Commerce and other organizations in their efforts to obtain sound legislation which will not only improve existing commercial arbitration but also prevent possible abuses.

First, the international merchant needs legislation in most countries of the world which will insure universal recognition of the validity of the arbitration clause, which will adequately define the powers of the arbitrators in all jurisdictions, and which will enable the enforcement of foreign arbitration awards in the jurisdictions of the losers.

But there should also be enacted protective legislation to allow the courts to invalidate arbitration awards in cases involving cartel control of patents or trade marks or other restrictive practices in the production and distribution of goods. The legislation should also clearly establish that if two parties enter into a contract that is contrary to public policy or contrary to the laws of the countries of either the buyer or the seller that the contract is obviously unenforceable and that arbitration is therefore invalid in such situations.

Whereas the powers of the arbitrators should be broad, an appeal to the higher courts should be possible in the event that the arbitrators are guilty of fraud or of dishonesty or of obvious prejudice.

Some of the weaknesses ascribed to international commercial arbitration are inherent in the business system as currently practiced. More fundamental changes than elimination of or emasculation of commercial arbitration are needed to correct these abuses. Weaknesses properly attributable to arbitration are few and minor 
compared with the great advantages in practice, particularly to the average exporter and importer who is limited in his knowledge of foreign trade techniques. Such exporters and importers are eager to avoid disputes with each other. When disputes do arise, their chief concern is for a speedy, economic and fair settlement of the disagreement so that they may continue their business relations with each other with harmony and good-will prevailing on both sides. A system of international arbitration conducted by tribunals of a high integrity and thoughtful understanding, and backed by laws of the international trading countries of the world, would give assurance to merchants and manufacturers of all countries that the barrier of commercial disputes can be easily surmounted. 